\title{
PENYULUHAN SISTEM ADMINISTRASI BADAN USAHA MILIK DESA DAN PELATIHAN AKUNTANSI BUMDES DI KECAMATAN KAUDITAN KABUPATEN MINAHASA UTARA
}

\author{
Lyndon Reinhard Jacob Pangemanan, Sherly Gladys Jocom \\ Jurusan Sosial Ekonomi Fakultas Pertanian \\ Universitas Sam Ratulangi Manado
}

\begin{abstract}
ABSTRAK
Potensi desa semakin memiliki peluang untuk dikembangkan seiring dengan lahirnya Undang-undang tentang desa. Pemanfaatan terhadap potensi desa dimanfaatkan untuk kepentingan masyarakat desa yang tujuannya mensejahterakan kehidupan masyarkat desa tersebut. Pembentukan Badan Usaha Milik Desa (BUMDes) adalah salah satu upaya pemerintah untuk menggerakkan ekonomi desa. BUMDes diharapkan menjadi lokomotif bagi berkembangnya ekonomi desa yang dapat mensejahterakan dan mengurangi kemiskinan masyarakat desa. Agar tujuan tersebut tercapai, BUMDes perlu dikelola secara profesional agar dapat bersaing dengan badan usaha lainnya. BUMDes Maudit dan BUMDes Esa Mokan dan BUMDes Treman merupakan BUMDes yang ada di Desa Kauditan I dan Desa Kauditan II serta Desa Treman. Dengan dukungan pemerintah desa, BUMDes ini mulai berjalan dengan perencanaan pengembangan usaha pada beberapa unit usaha yang potensial dikembangkan di desa tersebut. Permasalahan SDM menjadi kendala dalam pengembangan bisnis dari unit usaha yang ada karena masih rendahnya SDM yang dimiliki BUMDes terkait administrasi dan pembukuan atau pengelolaan keuangan BUMDes. Program Kemitraan Masyarakat (PKM) ini bertujuan untuk mengadakan Penyuluhan dan Pelatihan tentang Administrasi BUMDes dan Pelatihan Akuntansi Badan Usaha Milik Desa (BUMDes) di Kecamatan Kauditan dengan Mitra BUMdes Maudit Desa Kauditan I sebagai fokus pendampingan PKM. Output yang diharapkan adalah agar pengurus BUMDes memahami sistem administrasi Bumdes dan akuntansi/pembukuan serta memiliki kemampuan untuk membuat Laporan Keuangan BUMDes berupa akuntansi sederhana yaitu pembuatan buku kas harian, neraca, laporan rugi-laba dan laporan perubahan modal
\end{abstract}

Kata Kunci: Bumdes, penyuluhan, pelatihan, akuntansi 


\section{PENDAHULUAN}

\section{Analisis Situasi}

Undang-undang desa semakin membuka peluang pengembangan Potensi desa untuk di kelola guna kepentingan masyarakat desa. Desa memiliki banyak potensi untuk dikembangkan dan harus dikelola secara maksimal oleh masyarakatnya. Pemanfaatan terhadap potensi desa diperuntukkan untuk kepentingan masyarakat desa yang tujuannya mensejahterakan kehidupan masyarkat desa tersebut. Pembentukan Badan Usaha Milik Desa (BUMDes) adalah salah satu upaya pemerintah untuk menggerakkan ekonomi desa. BUMDes diharapkan menjadi lokomotif bagi berkembangnya ekonomi desa yang dapat mensejahterakan dan mengurangi kemiskinan masyarakat desa.

Apa yang dimaksud dengan Badan Usaha Milik Desa (BUMDes)? Dalam Permendagri No. 39 Tahun 2010 tentang Badan Usaha Milik Desa, sebagai turunan UU No. 32 Tahun 2004, BUMDes adalah usaha desa yang dibentuk/didirikan oleh Pemerintah desa yang kepemilikan modal dan pengelolaannya dilakukan oleh pemerintah desa dan masyarakat. Selanjutnya dalam UU No. 6 Tahun 2014, BUMDes adalah : badan usaha yang seluruh atau sebagian besar modalnya dimiliki oleh Desa melalui penyertaan secara langsung yang berasal dari kekayaan desa yang dipisahkan guna mengelola aset, jasa pelayanan Desa yang dipisahkan guna mengelola aset, jasa pelayanan, dan usaha lainnya untuk sebesarbesarnya kesejahteraan masyarakat.

Agar tujuan tersebut tercapai, BUMDes perlu dikelola secara profesional agar dapat bersaing dengan badan usaha lainnya. Salah satu cara agar BUMDes dapat berjalan maksimal adalah dengan pengelolaan keuangan yang dikelola dengan baik. BUMDes wajib untuk membuat laporan keuangan seluruh unit-unit usaha BUMDes setiap bulan dengan jujur dan transparan. Selain itu, BUMDes juga wajib memberikan laporan perkembangan unit-unit usaha BUMDes kepada masyarakat desa melalui musyawarah desa sekurang-kurangnya dua kali dalam satu tahun.

Secara umum, prinsip pembukuan keuangan BUMDes tidak berbeda dengan pembukuan keuangan lembaga lain pada umumnya. BUMDes harus melakukan pencatatan atau pembukuan yang ditulis secara sistematis dari transaksi yang terjadi setiap hari. Pencatatan transaksi itu umumnya menggunakan sistem akuntansi. Fungsi dari akuntansi adalah untuk menyajikan informasi keuangan kepada pihak internal dan eksternal dan sebagai dasar membuat keputusan. Pihak internal BUMDes adalah pengelola dan Dewan Komisaris, sedangkan pihak eksternal adalah pemerintah kabupaten, perbankan, dan masyarakat yang memberikan penyertaan modal, serta petugas pajak.

Tujuan pembukuan keuangan secara umum adalah:

1. Untuk mengetahui perkembangan perusahaan dari waktu ke waktu, baik perkembangan omzet penjualan, laba/rugi maupun struktur permodalan.

2. Untuk mengetahui kemungkinan kerugian sejak dini, sehingga gulung tikar bisa dihindari.

3. Untuk mengetahui kondisi persediaan barang/jasa setiap saat. Sehingga dapat digunakan untuk menyusun strategi manajemen persediaan. Pada unit usaha dagang yang disebut persediaan adalah barang dagangan. Pada unit usaha industri adalah persediaan bahan mentah, barang dalam proses maupun barang jadi. Sedang pada unit simpan pinjam yang disebut persediaan adalah persediaan uang.

4. Untuk mengetahui sumber dan penggunaan dana BUMDes, sehingga bisa mengevaluasi kinerja keuangan BUMDes.

Seperti laporan keuangan pada umumnya, beberapa istilah akuntansi umum juga digunakan dalam pembukuan keuangan BUMDes. Secara garis besar, ada empat istilah umum akuntansi yang digunakan dalam pembukuan BUMDes, yakni : Harta, Hutang, Biaya, dan Pendapatan.

Kecamatan Kauditan adalah salah satu Kecamatan di Kabupaten Minahasa Utara yang memiliki luas wilayah 12.178.KM2 dan 
terletak dibagian timur Kabupaten Minahasa Utara. Terdiri dari 12 Desa yaitu, : dari bagian timur yang berbatasan dengan Kota Bitung adalah Desa Watudambo II, Desa Watudambo, Desa Kauditan II, Desa kauditan I, Desa Kawiley , Desa Treman, Desa Kaima, Desa Karegesan , Desa Kaasar, Desa Lembean, Desa Paslaten dan Desa Tumaluntung, yang berbatasan dengan Kecamatan Airmadidi. Dari sekian desa di Kecamatan Kauditan, pemerintah Desa Kauditan I, dan Kauditan II serta Desa Treman memiliki perhatian yang besar terhadap penguatan Badan Usaha Milik Desa (BUMDES) untuk mendorong perekonomian desa. Hal ini dibuktikan dengan disepakatinya rencana pemberian dana penyertaan modal dari desa kepada Bumdes di Desa Kauditan I sebesar Rp. 100.000.000,- dan Rp. 50.000.000,- untuk Desa Kauditan II (Kawanua Post, 2018). Dana Penyertaan modal ini harus dikelola dengan baik dan transparan oleh pengurus Bumdes agar dana tersebut dapat digunakan untuk menggerakkan perekonomian masyarakat Desa Kauditan I dan Kauditan II. Untuk itu SDM yang mengelola Bumdes harus dibekali dengan pengetahuan tentang sistem Administrasi dan Pembukuan Bumdes.

BUMDes Desa Kauditan I bernama BUMDes Maudit, dalam perencanaannya akan fokus pada beberapa unit usaha yaitu:

1. Jasa Travel dan pangkalan gas

2. Pertanian, dengan Usha tani Jagung dan Cabe

3. Pengolahan ikan Cakalang Fufu dry ice

4. Jasa rental kursi

Sedangkan Bumdes Desa Kauditan II bernama BUMDes Esa Mokan, dan dalam perencanaannya akan fokus pada beberapa unit usaha yaitu:

1. Travel

2. Pengelolaan Gula Tare

3. Simpan Pinjam

Agar unit usaha dapat berkembang diperlukan strategi pengembangan bisnis dan hal ini masih sangat rendah dipahami oleh Pengurus BUMDes, sehingga menjadi masalah yang perlu dipecahkan.
Secara garis besar ada empat istilah umum akuntanMokasi yang digunakan dalam pembukuan BUMDES yakni ; Harta, Hutang, Biaya dan Pendapatan; Harta dalam pengertian akuntansi adalah semua barang dan hak milik BUMDES dan sumber ekonomi lainnya; Harta tetap, harta lancer dan harta tidak berwujud. Hutang merupakan kewajiban harus dibayar pada masa mendatang.Biaya adalah harta yang digunakan untuk menghasilkan pendapatan dalam satu periode tertentu yang habis terpakai.Pendapatan adalah peningkatan harta / activa bumdes sebagai akibat terjadinya transaksi yang menguntungkan. Dalam proses pengelolaan pembukuan keuangan Bumdes juga menggunakan standar yang sama dalam pembuatan bukti transaksi, seperti yang digunakan oleh pengguna akuntansi pada umumnya.

\section{Permasalahan Mitra}

Permasalahan yang dihadapai oleh Mitra sehubungan dengan Sistim Administrasi dan Pembukuan BUMDES di desa Kauditan 1 dan Kauditan II Kecamatan Kauditan adalah : Dilihat dari potensi ekonomi desa desa di Kecamatan Kauditan memiliki kekayaan sumber daya alam dibidang pertanian seperti tanaman kelapa, tanaman pala, tanaman cengkeh, serta tanaman palawija padi sawah, jagung, serta tanaman hortikultura buah buahan dan sayur sayuran maka peran BUMDes dalam pembiayaan ekonomi desa, baik dari sisi pembiayaan usahatani dan pemasaran. Disamping itu strategi pengembangan bisnis yang menjadi unit usaha BUMDes menjadi permasalahan yang penting untuk dicari solusinya.

Pertanyaan apakah kemampuan pengurus dibidang admnistrasi dan pembukuan BUMDES sudah mumpuni untuk mengelolah manajemen usaha yang baik melalui sistim adminstrasi dan pembukuan yang baik. Sumber daya manusia relatif memiliki kemampuan untuk mengelolah BUMDES, tapi perlu di bekali dengan penyuluhan dan pelatihan mengenai ketrampilan untuk mengelola BUMDES, 
khususnya di bidang admnistrasi dan keuangan, dengan demikian dapat menjawab keinginan masyarakat untuk mendapat pengurus BUMDES yang berkualitas, sehingga dalam pembiayaan dan memasarkan hasil pertanian dan non pertanian dapat dilakukan oleh BUMDES secara jujur dan transparan.

Permasalahan yang dihadapai oleh Mitra dalam pengelolaan keuangan BUMDes di Kecamatan Kauditan adalah masih rendahnya Sumber Daya Manusia (SDM) yang memiliki keahlian dalam pengelolaan keuangan. SDM dalam hal ini pengurus BUMDes di Desa-desa di Kecamatan Kauditan I masih belum memahami pengelolaan keuangan memalui Akuntansi sederhana. Pengelolaan keuangan melalui sistem administrasi sederhana perlu dilakukan agar unit usaha yang dikelola oleh BUMDes dapat berjalan baik dan berkelanjutan. Untuk mengatasi masalah tersebut diperlukan Pelatihan Akuntansi Badan Usaha Milik Desa (BUMDes) di Kecamatan Kauditan. Diharapkan dengan mengikuti Pelatihan Akuntansi BUMDES maka pengurus BUMDes dapat meningkatkan pemahaman dan ketrampilan dalam mengelola keuangan BUMDes sehingga menjadi transparan dan dapat dipertanggungjawabkan.

\section{Tujuan dan Manfaat}

Kegiatan pengabdian kepada masyarakat yang dilaksanakan di Kecamatan Kauditan ini bertujuan untuk:

1. Meningkatkan kemampuan dan pemahaman Pengurus BUMDes terkait Sistem Administrasi BUMDES

2. Transfer Ilmu dan Pengetahuan sehingga ketrampilan pengurus BUMDes tentang pengelolaan keuangan BUMDES berupa Akuntansi sederhana lebih terampil.

Kegiatan pengabdian kepada masyarakat ini diharapkan dapat memberikan manfaat :

1. Perubahan Kapasitas SDM.

2. Kepemimpinan yang transparansi dan akuntabel melalui penguasaan ketrampilan administrasi dan akuntansi sederhana BUMDES.

\section{METODE}

Berdasarkan permasalahan yang dihadapai BUMDes di Desa Kauditan 1 dan Kuuditan II serta Desa Treman, terlihat masih rendahnya SDM yang dimiliki BUMDes di masing-masing Desa dalam mengelola BUMDes. Untuk itu perlu penguatan dalam meningkatkan kemampuan SDM BUMDes melalui penyuluhan dan pelatihan terkait peluang mengembangkan unit usaha yang produktif dan pelatihan Akuntansi BUMDes.

\section{Penyuluhan}

Penyuluhan akan dilakukan kepada pengurus BUMDes yang ada di 3 desa di Kecamatan Kauditan yaitu Desa Kauditan I, Desa Kauditan II dan Desa Treman, namun pendampingan secara khusus hanya dilakukan pada Pengurus BUMDes Desa Kauditan 1 sebagai Mitra.

Penyuluhan yang dilakukan terkait melihat potensi mengembangkan unit usaha yang dapat dikelola berdasarkan sumberdaya yang tersedia di masing-masing desa serta bagaimana strategi mengembangkan bisnis dari unit-unit usaha tersebut.

\section{Pelatihan}

Pelatihan diperlukan untuk menambah ketrampilan dari pengurus BUMDes, pelatihan yang diberikan terkait pengelolaan Keuangan Bumdes dengan menggunakan Akuntansi sederhana BUMDes. Pelatihan akan diberikan kepada Pengurus BUMDes yang ada di Desa Kauditan I, DKAuditan II dan Treman. Akan tetapi pendapingan khusus akan dilakukan kepada Mitra yaitu Pengurus BUMDes Maudit Desa Kauditan I.

\section{HASIL DAN PEMBAHASAN}

\section{Survey Lapangan}

Survey Lapangan dilakukan untuk mensosialisasikan kegiatan Penyuluhan dan Pelatihan dengan Mitra dan Pemerintah Kecamatan Kauditan. Pada kesempatan ini dibahas tentang peserta yang akan hadir dalam kegiatan dan pelaksanaan kegiatan penyuluhan dan pelatihan Bumdes. Hasil diskusi antara 
Pemerintah Kecamatan diwakili oleh Sekretaris Kecamatan dan Tim Kerja Pelaksana Kegiatan dan Mitra, desa yang terwakili di Kecamatan Kauditan ada 3 desa yaitu Desa Kauditan I, Desa Kauditan II dan Desa Treman. Pertimbangan ketiga desa tersebut mempunyai BUMDES dan mendapat dana penyertanaan modal dari pemerintah.

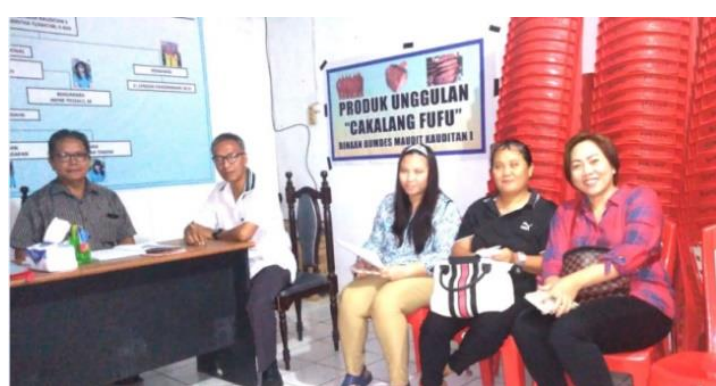

Gambar 1. Sosialisasi Kegiatan kepada Mitra

\section{Pelaksanaan Kegiatan}

Kegiatan Penyuluhan dan Pelatihan dilaksanakan pada tanggal 28 Juni 2019 di ruang pertemuan Kecamatan Kauditan. Kegiatan dihadiri oleh 3 Bumdes yang mewakili 3 Desa di Kecamatan Kauditan. Bumdes "Maudit" Desa Kauditan I, Bumdes "Esa Mokan" Desa Kauditan II dan Bumdes "Tareuman Jaya" Desa Treman. Bumdes Maudit Desa Kauditan I merupakan Mitra dalan Kegiatan PKM Unsrat.

Pelaksanaan berlangsung dengan baik dan lancar serta didukung oleh pemerintah desa dan pemerintah Kecamatan Kauditan serta Pemerintah Kabupaten Kauditan. Peserta yang hadir adalah 35 orang peserta yang terdiri dari pemerintah desa dan pengurus BUMDES Maudit Desa Kauditan I, Pengurus BUMDES Esa Mokan Desa Kauditan II dan Pengurus BUMDES Tareuman Jaya Desa Treman. Kegiatan PKM ini merupakan kolaborasi dari Pemerintah Desa Kauditan I, Pemerintah Desa Kauditan II dan Pemerintah
Desa Treman dengan Tim Pengabdian Masyarakat dari LPPM Unsrat. Pemerintah Kabupaten pada kesempatan ini mensosialisasikan dana penyertaan modal yang akan diberikan kepada BUMDES sebesar Rp.100.000.000,- Dana ini akan dicairkan apabila BUMDES sudah memiliki bisnis plan yang baik. Untuk lebih menguatkan SDM Bumdes, Tim LPPM Unsrat mengambil bagian dengan memberikan materi bagaimana membuat proposal usaha yang baik untuk Bumdes.

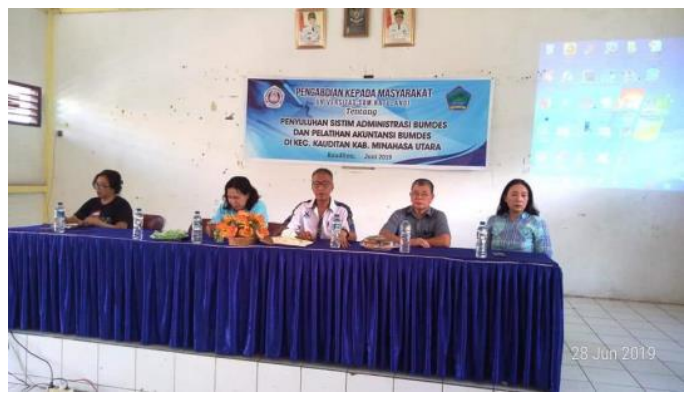

Gambar 2. Nara Sumber Kegiatan Pelatihan dan Penyuluhan.

Kegiatan PKM di buka oleh Sekretaris Camat Kauditan Ibu Bertha Loutje Katuuk, SP. Narasumber untuk sosialisasi dari pemerintah adalah Kabid Pemberdayaan Masyarakat Ibu Diane Rumambi Sedangkan Materi pelatihan diberikan oleh Ir. Lyndon Pangemanan, ME dan Ir. Eyverson Ruaw, MSi. Ir. Lyndon Pangemanan, ME merupakan Pengawas serta Pengurus Bumdes Desa Kauditan I serta dosen Fakultas Pertanian dan Ir. Eyverson Ruaw, MSi merupakan dosen Akuntansi di Fakultas Pertanian yang banyak berkecimpung dalam kegiantan pelatihan akuntansi. Kegiatan pelatihan di tutup dengan sesi diskusi, berupa tanya jawab dari peserta pelatihan. 


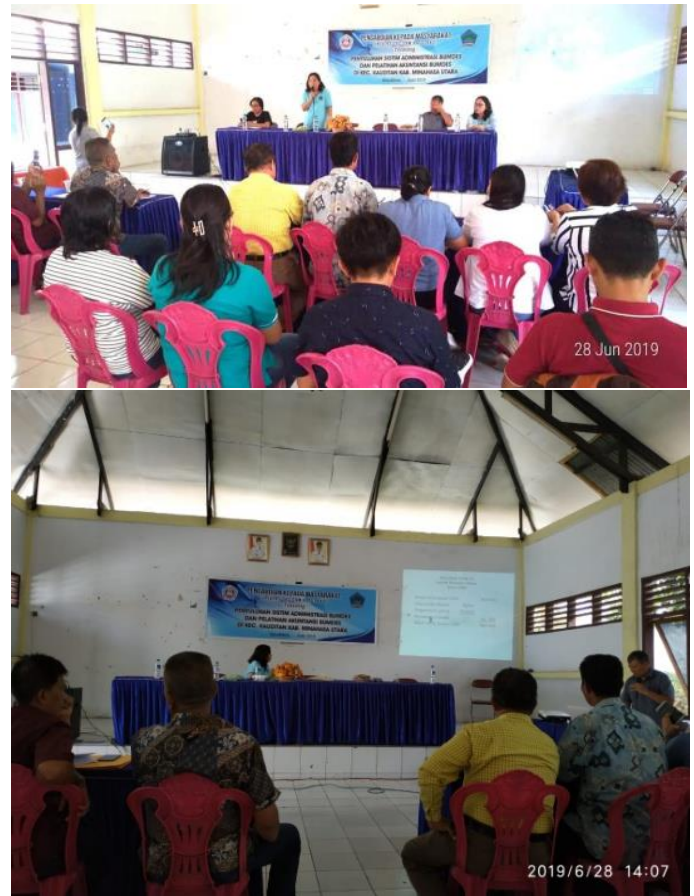

Gambar 3. Foto Pelaksanaan Kegiatan Penyuluhan dan Pelatihan

\section{Pendampingan dan Evaluasi}

Setelah Pelaksanaan kegiatan penyuluhan dan pelatihan, diadakan pendampingan kepada Mitra PKM dalam hal ini Bumdes Maudit Desa Kauditan I. Pendampingan dilaksanakan 3 kali dan terdiri dari pendampingan terkait pembuatan laporan keuangan, peninjauan unit-unit usaha yang dikelola oleh Bumdes Desa Maudit dan Output atau luaran yang dihasilkan yaitu draft Laporan Keuangan yang akan dimasukkan kepada pemerintah sebagai bentuk pertanggungjawaban Bumdes terhadap Dana Penyertaan Modal yang sudah disalurkan kepada Bumdes.

\section{a. Pendampingan Pembuatan Laporan Keuangan}


EDUPRENEUR || Vol. 2, No 3, November 2019

Jurnal Pengabdian Kepada Masyarakat Bidang Kewirausahaan

\section{a. Pendampingan Pembuatan Laporan} Keuangan

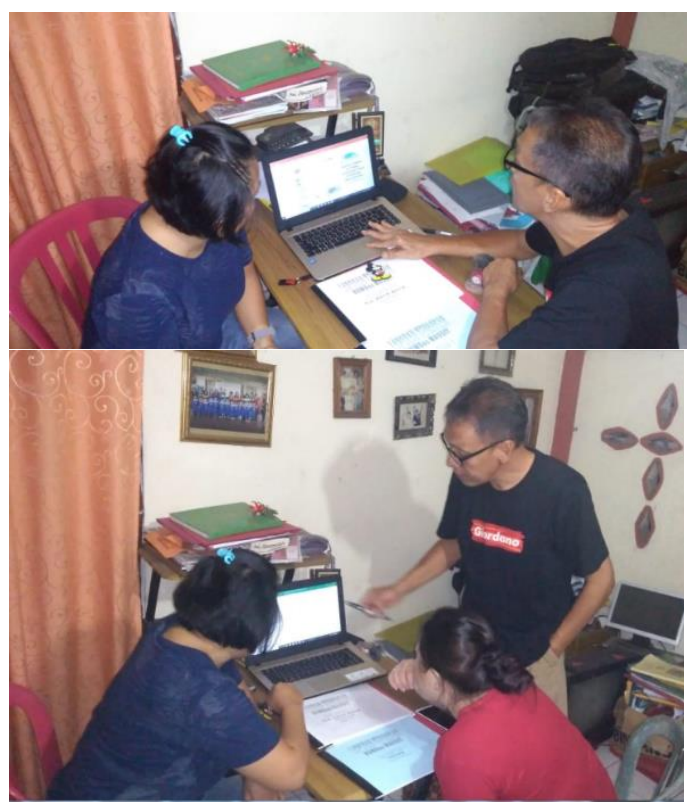

Gambar 4. Pendampingan Pembuatan Laporan Keuangan

\section{b. Pendampingan Peninjauanan Unit Usaha Bumdes}

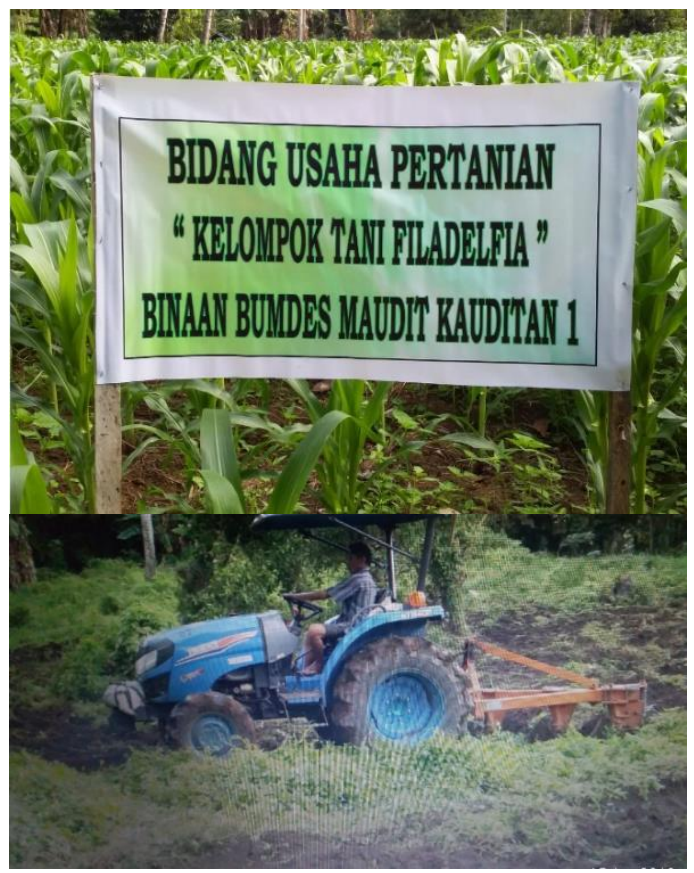

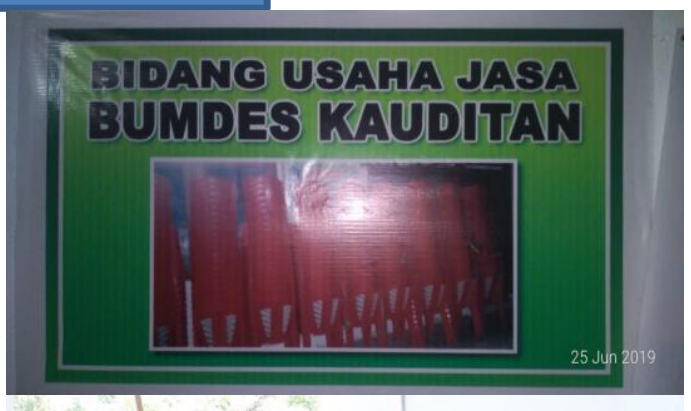
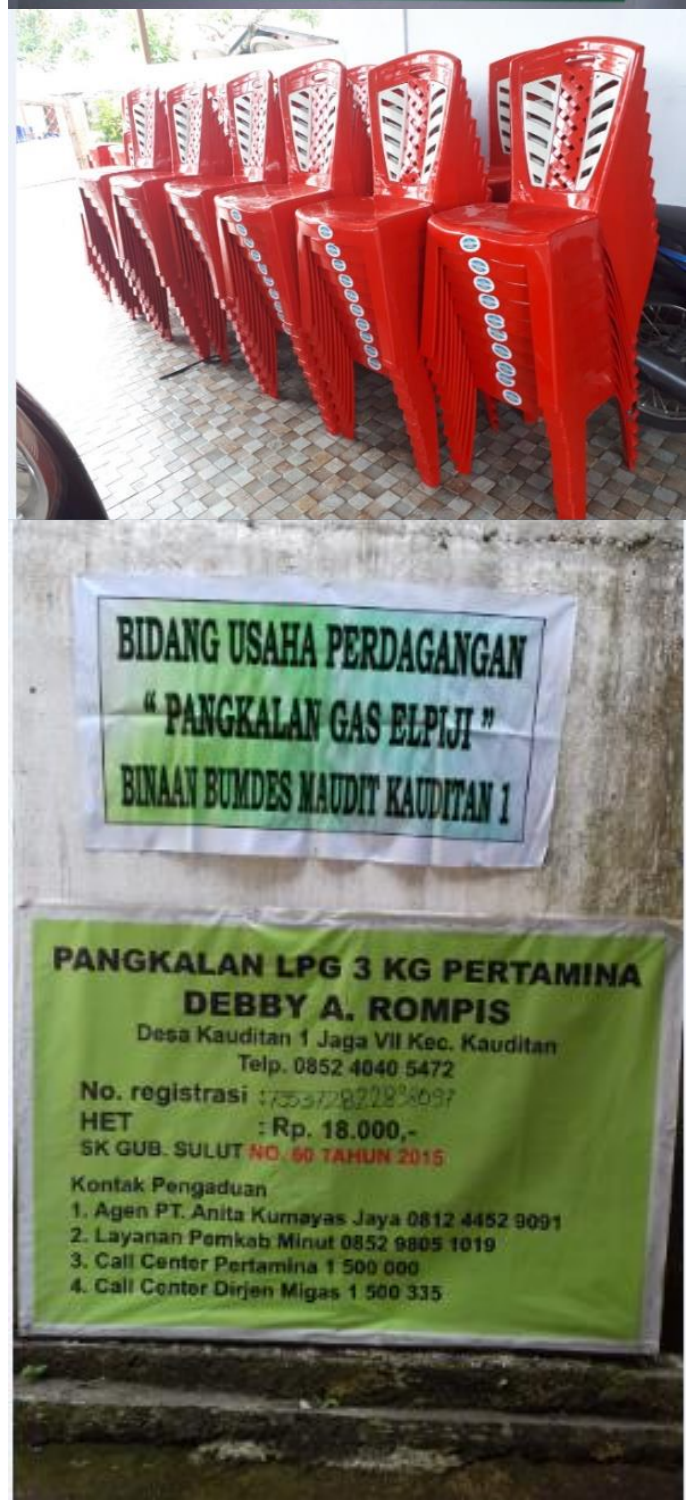

Gambar 5. Unit Usaha Mitra 


\section{c. Bumdes Desa Maudit mampu membuat Laporan Keuangan}

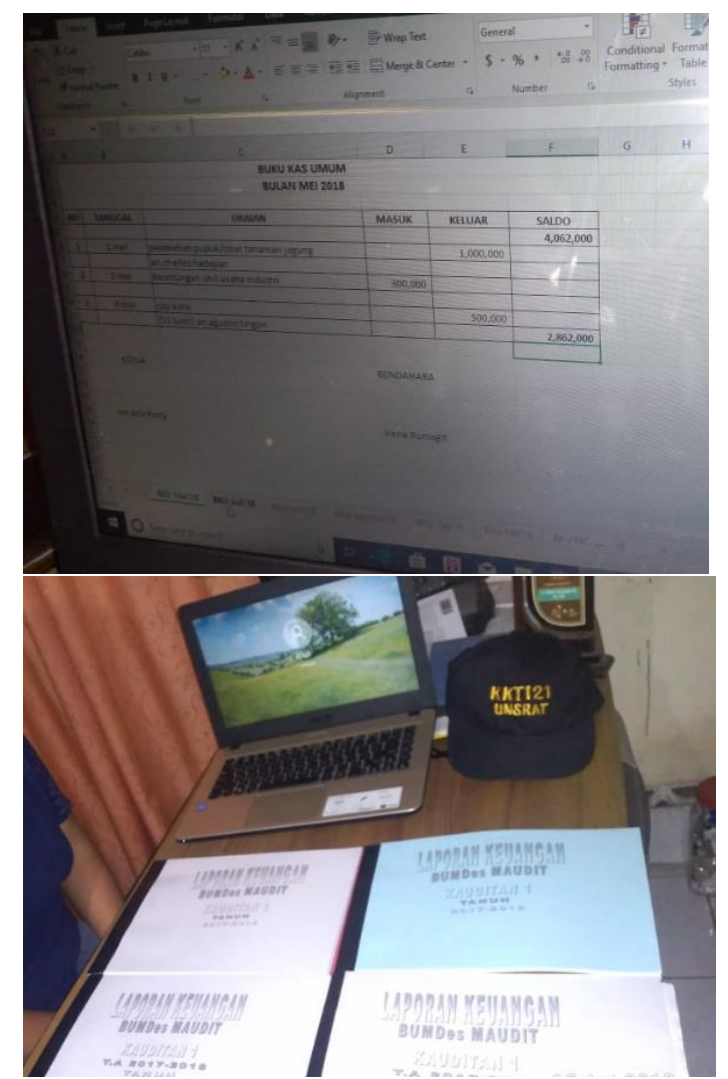

Gambar 5. Luaran /Output Laporan Keuangan Mitra

Hasil yang dicapai dalam kegiatan pelatihan ini adalah:

1. Mitra menjadi paham dan mengerti apa yang dimaksud dengan Akuntansi BUMDES
2. Mitra dapat mengerti pentingnya pencatatan dalam setiap transaksi

3. Mitra dapat membuat buku kas harian, Neraca dan Laporan rugi laba serta perubahan modal.

Mitra Mampu membuat Laporan Keuangan BUMDES sebagai bentuk pertanggungjawaban atas penggunaan dana pernyertaan Modal dari Pemerintah.

\section{KESIMPULAN}

Pelatihan Pembuatan Proposal Usaha BUMDes di Kecamatan Kauditan memberikan manfaat positif bagi pengurus BUMDES Maudit Desa Kaudita I, Pengurus BUMDES Esa Mokan Desa Kauditan II dan Pengurus BUMDES Desa Treman dimana Pengurus mampu memahami tentang akuntansi dan pembukuan serta mampu membuat Laporan Keuangan BUMDES sebagai bentuk pertanggungjawaban pengurus dalam penggunaan Dana Penyertaan Modal yang telah digulirkan pemerintah.

\section{REFERENSI}

BPS 2017. Kecamatan Kauditan Dalam Angka, BPS Dan Bappeda Minahasa Utara.

Wind, A. 2014 Buku Saku "Akuntansi Edisi Paling Lengkap Secara Otodidak. Penerbit. Laskar Aksara. Jakata Timur

http://www.keuangandesa.com/2015. Pembukuan Keuangan Badan Usaha Milik Desa.

http://www.elnusanews.com/2018/09/lewatsosialisasi-bumdes-kauditan-satu.html Lewat Sosialisasi, Bumdes Kauditan Satu Lebih Diperkuat. 